\title{
AN EXERTION OF ENHANCE MILK YIELD OF NATIVE PABNA CATTLE THROUGH USING DIFFERENT TYPES OF CALCIUM SALT OF FATTY ACID
}

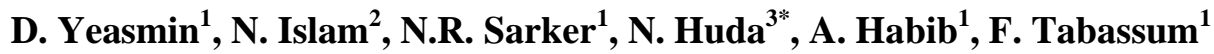 \\ ${ }^{1}$ Fodder Research and Development Project, Bangladesh Livestock Research Institute \\ Savar, Dhaka, Bangladesh \\ ${ }^{2}$ Department of Dairy Science, Bangladesh Agricultural University, Mymenshing, Bangladesh \\ ${ }^{3}$ Animal Production Research Division, Bangladesh Livestock Research Institute
} Savar, Dhaka, Bangladesh

\begin{abstract}
Keeping consideration on increasing quality milk production through addition of conventional fat, an experiment accords CRD design was conducted at Bangladesh Livestock Research Institute, Savar, Dhaka for a period of 30 days including 5 days of digestibility trial. Twenty lactating Pabna cattle of average $250.1 \pm 13.64 \mathrm{~kg}$ (Bos indicus) of initial body weight with average milk yield of $2.88 \pm 0.38 \mathrm{~kg}$ were selected and divided into four groups randomly having five cows in each. The imposed treatments were $\mathrm{T}_{0}, \mathrm{~T}_{1}, \mathrm{~T}_{2}$, and $\mathrm{T}_{3}$; in where $\mathrm{T}_{0}=$ German grass + Concentrate mixture without $\mathrm{Ca}$ salt of fatty acid $+2.5 \% \mathrm{DCP}, \mathrm{T}_{1}=$ German grass + Concentrate mixture $+2.5 \%$ soybean based Ca salt of fatty acid, $\mathrm{T}_{2}=$ German grass + Concentrate mixture $+2.5 \%$ mustard based $\mathrm{Ca}$ salt of fatty acid and $\mathrm{T}_{3}=$ German grass + Concentrate mixture $+2.5 \%$ palm-oil based Ca salt of fatty acid. The result showed that, calcium salt of fatty acid influenced to increase of milk yield significantly among $(\mathrm{P}<0.001)$ the treatments; in where highest yield gained in $T_{1}$ $\left(3.53 \mathrm{~kg} \mathrm{~d}^{-1}\right.$ ) followed by $T_{2}, T_{0}$ and $T_{3}(3.33,2.44$ and 2.24 , respectively). Besides this, all other parameters analytically examined in this experiment i.e. intake, apparent digestibility, gained body weight and chemical composition of milk showed non-significant difference among the treatments. From the analytical value and discussion, it may be suggested that, calcium salt of fatty acid formulated from soybean oil or mustard oil could be used for enhancing better quality milk yield.
\end{abstract}

Keywords: Ca salt of fatty acid, milk yield, chemical composition of milk, nutrient intake, nutrient digestibility, gained weight

\section{INTRODUCTION}

For tactful diet formulation with much more energy than conventional fat consults addition of fat as feed in the diet very commonly. The supplemental fat of diet,

* Corresponding author e-mail: hudanazmul1971@gmail.com 
provide calories and as well as impacts on tissue metabolism by altering genetic expression (Sumida et al., 1993) or on supplying precursors (acetyl Co-A) for synthesis of other fatty acids or steroids (Staples et al., 1998), or competing with other cell components (Thatcher et al., 2004). In addition, metabolizible energy in the form of supplemental fat is utilized more efficiently than that contained in cereals and forage (Palmquist and Jenkins, 1980). And, another beautiful mechanism is, rumen inert fat can enhance energy density of lactation diets without adversely affecting fiber digestion; thus, effectively overcome the shortcomings of conventional fat being introduced in the rumen (Jenkins and Palmquist 1984; Grummer, 1988). The development of $\mathrm{Ca}$ salts of fatty acids (CaFA), which are considered inert in the rumen, offers a method of increasing production and efficiency without impairing fermentative digestion (Chalupa et al., 1986). In this regard, several experiments had done and they suggested that, inclusion of Ca salts of FA increased overall milk production of dairy cows (Moallem et al., 2000); by means of milk yield or milk fat percentage (Klusmeyer et al., 1991) or both (Rabiee et al., 2012). A major concern is, "Ca salts" are thought to be insoluble in the rumen which resembles an experiment; in where a higher proportion of unsaturated FA in duodenal digesta when a diet containing Ca salts of FA from palm oil was fed (Wu et al., 1991). But, it is more established that, calcium salt of fatty acid have possible protection against biohydrogenation depending on the conditions in rumen and if feeding saturated fats or Ca salts of long chain fatty acids are practiced, then it may minimize any detrimental effects on ruminal fermentation and saturated fatty acids are less likely to alter fermentation in the rumen than unsaturated fatty acids, because saturated fatty acids are less soluble and therefore, are less likely to absorb by bacteria (Chalupa et al., 1984). Saturated fatty acids also react more readily with metal ions to form insoluble salts of fatty acids (Palmquist and Jenkins, 1982) and preformed Ca salts of fatty acids $(\mathrm{CaS})$ does not alter fermentation in the rumen because of their insolubility (Chalupa et al., 1984 and Chalupa et. al., 1986). It is exercised and proved that, supplementation of calcium salts of long chain fatty acids (Ca-LCFA) as a rumen inert fat (PF) has no detrimental effect on fermentation and apparent nutrient digestion (Naik et al., 2009). Even ruminal pH, total VFA, molar percentage acetate propionate, and milk yield and fat percentage were not affected by fat supplementation (Grummer, 1988). Moreover, calcium salts of palm oil fatty acids at a $4 \%$ level in the concentrate mixture resulted with improved milk production and milk quality in terms of polyunsaturated fatty acids without affecting the digestibility of nutrients (Sajith et al., 2008). For a long time, supplemental fat is increasingly included in the diets of high yielding dairy cows (Kellogg et al., 2001). This allows to modify the fatty acids (FA) pattern of the milk fat (Precht et al., 2001) and to improve the energy supply of the cow. Furthermore, supplemental fat act as nutritional modifier of physiology and metabolism (Voigt et al., 2005). However, unprotected, unsaturated FA can be toxic to the rumen microbes unless saturated by microbial hydrogenation (Harfoot, 1981). There are different commercial sources of 
rumen inert fats including hydrogenated fatty acids and calcium salts of fatty acids and these fat sources were originally designed to increase the calorie intake of dairy cows with minimal impact on rumen microbial activity indeed. In aspect of improved milk production and altering composition of milk fat, there has no doubt on influencing supremacy of Calcium salt of fatty acid. But, regarding this context, a few works have done in Bangladesh. So very logically, this experiment was undertaken to find out the effect of feeding different types of calcium salt of fatty acids on feed intake, digestibility, milk yield, milk composition of dairy cow and finally to recommend a perfect one.

\section{MATERIALS AND METHODS}

An experiment accords CRD design was conducted at "Pachutia Cattle Research Farm" of Bangladesh Livestock Research Institute (BLRI), Savar, Dhaka for a period of 30 days including 5 days of digestibility trial from 10 September, 2013 to 10 October, 2013. Twenty lactating Pabna cattle of average $250.1 \pm 13.64 \mathrm{~kg}$ (Bos indicus) of initial body weight with average milk yield of $2.88 \pm 0.38 \mathrm{~kg}$ were selected and divided into four groups randomly having five cows in each with maintained similarity of body weight and milk yield of each group as much as possible. These groups were then imposed to treatments of $\mathrm{T}_{0}, \mathrm{~T}_{1}, \mathrm{~T}_{2}$, and $\mathrm{T}_{3}$; in where $\mathrm{T}_{\mathrm{o}}=$ German grass + Concentrate mixture without Ca salt of fatty acid $+2.5 \%$ $\mathrm{DCP}, \mathrm{T}_{1}=$ German grass + Concentrate mixture $+2.5 \%$ soybean based Ca salt of fatty acid, $\mathrm{T}_{2}=$ German grass + Concentrate mixture $+2.5 \%$ mustard based Ca salt of fatty acid and $\mathrm{T}_{3}=$ German grass + Concentrate mixture $+2.5 \%$ palm oil based $\mathrm{Ca}$ salt of fatty acid. Due to the abundance of German grass at research farm it was used as basal diet of cow. Three different types of calcium salt of fatty acid were prepared using sodium hydroxide $(\mathrm{NaOH})$ solution and saturated solution of calcium chloride $\left(\mathrm{CaCl}_{2}\right)$. As for soybean oil, at first five parts of soybean oil were added to four parts of aqueous solution of $\mathrm{NaOH}(6 \mathrm{M})$ and the hydrolysis of oil triacylglycerols was performed at 95 to $100^{\circ} \mathrm{C}$ with continuous agitation and bubbling $\mathrm{Na}$. When no more soybean oil was visible, the resulting blend was left to stand at $5^{\circ} \mathrm{C}$ until $\mathrm{Na}$ soaps had solidified. The Na soaps then were dissolved in hot water $\left(95\right.$ to $\left.100^{\circ} \mathrm{C}\right)$ using a 1:5 ratio of soap to water, and a saturated solution of $\mathrm{CaCl}_{2}$ at a ratio of 2.5 parts and 4.5 parts of soap to water was added for salting out. A filter cloth was used to filter the $\mathrm{Ca}$ salts, and tap water was used to remove residual $\mathrm{NaOH}$ and excess $\mathrm{CaCL}_{2}$. The Ca salts were finally dried both in air and sun, and kept at about $20^{\circ} \mathrm{C}$ until use for feeding. For mustard oil and palm oil same manner was followed. Preparation of Ca salt of fatty acid was done on the basis of availability of ingredient by modifying the method of Chouinard et al. (1998). The concentrate mixture was prepared by weighing and mixing of wheat bran (45\%), maize crushed (10\%), wheat crushed (10\%), soybean meal (5\%), til oil cake (10\%), kheshari (15\%), fish meal (2\%), salt $(0.5 \%)$, DCP or Calcium salt of fatty acids (2.5\%) manually. The nutrient composition of concentrate mixture was dry matter $(90.21 \%)$, organic matter 
(91.49\%), crude protein (16.07\%), ADF (21.29\%), NDF (55.69\%) and ash (8.51\%). All the ingredients were mixed properly and then allowed to animals. The amount of supplied and refused feeds was recorded everyday and from there actual feed intake of each animal was found out periodically after every fortnight and then incremental feed was adjusted to the animal diets. The nutrient requirements of animal (varying amount of milk production) were calculated based on the recommendation of NRC, 1984. Live weight of all animals were also measured fortnightly at morning with empty stomach. Animals were housed in individual well equipped stanchion barn and offered concentrate rations as two equal portions at 6:00 and 13:00 $\mathrm{h}$ before milking and roughages was offered thrice a day; as one third at morning after milking and remaining two third at noon after milking again. Abundant clean water was made available all the period of experiment and prior to experiment, all the cows were dewormed for internal parasites using Tetranid Bolus (Techno Drugs, Bangladesh). A conventional digestion trial was performed for 5 days at the end of feeding trial and that time feed intake, refusal of feed and was recorded daily. Composite samples of supplied feed, residue and feces of individual animal were stored at $-20{ }^{\circ} \mathrm{C}$. At the time of chemical analysis, $1 \mathrm{~mm}$ screen sieve was used for mixed dried feces except DM and CP. Samples of fresh fodder, concentrates, feed refusals and feces were analyzed for dry matter $(\mathrm{DM})$, organic matter $(\mathrm{OM})$, crude protein $(\mathrm{CP})$, neutral detergent fiber (NDF) and acid detergent fiber (ADF). DM contents by oven drying at $105{ }^{0} \mathrm{C}$ for overnight, ash at $550{ }^{0} \mathrm{C}$ for $8 \mathrm{~h}$, total nitrogen $(\mathrm{N})$ by Kjeldahl procedure and $\mathrm{CP}$ calculation from $\mathrm{N}$ content $(\mathrm{CP}=\mathrm{N} \times 6.25)$ according to the official methods of AOAC (2005) were determined. NDF and ADF were determined following procedure proposed by Goering and Van Soest (1970). Apparent digestibility coefficient for DM, OM, CP, NDF and ADF was calculated from dietary intake of constituent and amount recovered in feces. Milk samples were collected from each cow at 15 days interval and were analyzed for fat, protein, lactose, SNF and total ash contents by milk analyzer (Lactostar, Funk Gurbar). The data were analyzed using "MSTAT-C" statistical program to compute analysis of variance (ANOVA) for a Complete Randomized Design (CRD) and the mean values with standard error of difference (SED) were recorded. The difference among the treatment means were determined by Duncan's Multiple Range Test (Steel and Torrie, 1980).

\section{RESULTS}

In this experiment, all the intake parameters of nutrients showed that, they are nonsignificant among the treatments. In case of total dry matter intake, little bit highest value observed in $\mathrm{T}_{1}$ (2.5\% soybean oil based calcium salt of fatty acid) treatment with $7.99 \mathrm{~kg} \mathrm{~d}^{-1}$ followed by $\mathrm{T}_{3}\left(2.5 \%\right.$ palm oil based calcium salt of fatty acid), $\mathrm{T}_{2}$ ( $2.5 \%$ mustard oil based calcium salt of fatty acid) and $\mathrm{T}_{0}$ (without calcium salt of fatty acid) (7.93, 7.92 and 7.84), respectively. Result of dry matter intake from roughage varied as same before but in case of DMI of concentrate it was different as before (Table1). The metabolizeble energy requirement of different treatments were 
50.4, 49.4, 47.6 and $50.0\left(\mathrm{~T}_{0}, \mathrm{~T}_{1}, \mathrm{~T}_{2}\right.$ and $\left.\mathrm{T}_{3}\right)$, respectively (Table1). And, after the experiment, increased ME intake was observed with all the treatments. Among the treatments, highest MEI value was observed in $\mathrm{T}_{1}$ with $55.4 \mathrm{MJ} \mathrm{d}^{-1}$ followed by $\mathrm{T}_{0}$, $\mathrm{T}_{3}$ and $\mathrm{T}_{2}$ (54.4, 53.6 and 50.8, respectively), shown in table1. Same manner was seen in the context of $\mathrm{ME}$ intake from roughage i.e. highest in $\mathrm{T}_{1}$ with $37.0 \mathrm{MJ} \mathrm{d}^{-1}$ followed by $\mathrm{T}_{0}, \mathrm{~T}_{3}$ and $\mathrm{T}_{2}(36.2,34.8$ and 32.6, respectively), shown in table1. But, from concentrate $\mathrm{T}_{3}$ treatment harvest the highest ME i.e. $18.8 \mathrm{MJ} \mathrm{kg}^{-1}$. In case of crude protein intake, highest total crude protein intake was observed in $\mathrm{T}_{3}$ treatment with $995.2 \mathrm{gm} \mathrm{d}^{-1}$ followed by $\mathrm{T}_{0} \& \mathrm{~T}_{1}$ and $\mathrm{T}_{2}$ (994.4 and 992.4, respectively), shown in Table1. CP intake from roughage was observed as same manner as intake of total CP. From concentrate, highest crude protein was ingested by $\mathrm{T}_{0}\left(385.4 \mathrm{gm} \mathrm{d}^{-1}\right)$ followed by $\mathrm{T}_{1}, \mathrm{~T}_{3}$ and $\mathrm{T}_{2}$ (384.6, 384.4 and 383.6 , respectively), shown in table1. The effect of calcium salt of fatty acid on apparent digestibility of different treatments for all the parameters were also found non-significant. Highest dry matter and crude protein digestibility was found in $\mathrm{T}_{0}$ ( 71.68 and 72.04 , respectively) followed by $\mathrm{T}_{3}$, $\mathrm{T}_{2}$ and $\mathrm{T}_{1}(71.24 \& 71.39,71.05 \& 71.29$ and $69.31 \& 69.23$, respectively), shown in table1. The effect of different types of calcium salt of fatty acid was clearly visible with the milk yield of different treatments. The average daily milk yield of whole experimental period were $2.44,3.53,3.33$ and $2.24 \mathrm{~kg}$ in treatment groups $\mathrm{T}_{0}$ (without calcium salt of fatty acid), $\mathrm{T}_{1}(2.5 \%$ soybean oil based calcium salt of fatty acid), $\mathrm{T}_{2}(2.5 \%$ mustard oil based calcium salt of fatty acid $)$ and $\mathrm{T}_{3}(2.5 \%$ palm oil based calcium salt of fatty acid), respectively; which differed significantly $(\mathrm{P}<0.001)$ among treatments with gained highest yield in $\mathrm{T}_{1}\left(3.53 \mathrm{~kg} \mathrm{~d}^{-1}\right)$ followed by $\mathrm{T}_{2}, \mathrm{~T}_{0}$ and $\mathrm{T}_{3}\left(3.33,2.44\right.$ and 2.24 , respectively), shown in table 2 . Here, $\mathrm{T}_{1}$ did not differed significantly with $T_{2}$ and $T_{0}$ also did not differed significantly with $T_{3}$ but $T_{1} \& T_{2}$ together differed significantly $(\mathrm{P}<0.001)$ with other two treatment groups i.e. $\mathrm{T}_{0} \& \mathrm{~T}_{3}$. This result indicates significant improvement in milk yields distinctly due to supplementation of Calcium salt of fatty acid. However, the compositions of milk against fed different diets represented the result differently. The average milk fat content of $\mathrm{T}_{0}, \mathrm{~T}_{1}, \mathrm{~T}_{2}$ and $\mathrm{T}_{3}$ groups were $4.01,3.35,3.55$ and $3.66 \mathrm{~g} \mathrm{~kg}^{-1}$ of milk, respectively. There was no significant difference $(\mathrm{p}>0.05)$ in terms of fat, protein, lactose, total minerals (estimated) or solids not fat $\left(\mathrm{g} \mathrm{kg}^{-1}\right)$ among treatments (Table 2). Finally, very logically as all animals of each treatment got the same quality feed ingredient except $\mathrm{Ca}$ salts of fatty acid then any significant difference of live weight gain among treatments was not occurred (Table 3). 
Table 1. Effect of different types of calcium salt of fatty acid on intake and digestibility of different treatment groups of Pabna lactating cow

\begin{tabular}{|c|c|c|c|c|c|}
\hline \multirow[t]{2}{*}{ Parameter } & \multicolumn{4}{|c|}{ Mean \pm SE of different treatment group } & \multirow{2}{*}{$\begin{array}{l}\text { Level of } \\
\text { significance }\end{array}$} \\
\hline & $\mathrm{T}_{0}$ & $\mathrm{~T}_{1}$ & $\mathrm{~T}_{2}$ & $\mathrm{~T}_{3}$ & \\
\hline $\begin{array}{c}\mathrm{ME}(\mathrm{MJ}) \\
\text { requirement }\end{array}$ & $50.40 \pm 2.03$ & $49.40 \pm 3.05$ & $47.60 \pm 3.74$ & $50.00 \pm 3.78$ & NS \\
\hline $\begin{array}{l}\text { DMI from roughage } \\
\qquad(\mathrm{kg})\end{array}$ & $5.45 \pm .068$ & $5.62 \pm .094$ & $5.53 \pm .14$ & $5.58 \pm .079$ & NS \\
\hline $\begin{array}{l}\text { DMI from concentrate } \\
\qquad(\mathrm{kg})\end{array}$ & $2.37 \pm .046$ & $2.37 \pm .085$ & $2.38 \pm .076$ & $2.35 \pm .022$ & NS \\
\hline Total DMI (kg) & $7.84 \pm .06$ & $7.99 \pm .12$ & $7.92 \pm .21$ & $7.93 \pm .09$ & NS \\
\hline ME from roughage $(\mathrm{MJ})$ & $36.20 \pm 1.83$ & $37.00 \pm 2.47$ & $32.60 \pm 2.06$ & $34.80 \pm 2.48$ & NS \\
\hline ME from conc. $(\mathrm{MJ})$ & $18.20 \pm .58$ & $18.40 \pm .51$ & $18.20 \pm .80$ & $18.80 \pm .66$ & NS \\
\hline Total ME intake (MJ) & $54.40 \pm 1.75$ & $55.40 \pm 2.25$ & $50.80 \pm 2.39$ & $53.60 \pm 3.08$ & NS \\
\hline $\mathrm{CP}$ from roughage $(\mathrm{g})$ & $609.00 \pm 2.19$ & $609.80 \pm 3.01$ & $608.80 \pm 2.73$ & $610.80 \pm 1.36$ & NS \\
\hline $\mathrm{CP}$ from conc. $(\mathrm{g})$ & $385.40 \pm 1.21$ & $384.60 \pm 3.19$ & $383.60 \pm .93$ & $384.40 \pm .68$ & NS \\
\hline Total CP intake (g) & $994.40 \pm 1.50$ & $994.40 \pm 1.78$ & $992.40 \pm 2.23$ & $995.20 \pm 1.32$ & NS \\
\hline Digestibility of DM & $71.68 \pm 2.08$ & $69.31 \pm 1.65$ & $71.05 \pm 1.81$ & $71.24 \pm 1.17$ & NS \\
\hline Digestibility of OM & $69.05 \pm 1.18$ & $66.74 \pm 1.57$ & $69.05 \pm 1.18$ & $69.05 \pm 1.18$ & NS \\
\hline Digestibility of CP & $72.04 \pm 2.21$ & $69.23 \pm 1.44$ & $71.29 \pm 1.14$ & $71.39 \pm 1.07$ & NS \\
\hline Digestibility of ADF & $68.26 \pm 1.21$ & $65.89 \pm 1.61$ & $68.26 \pm 1.21$ & $68.26 \pm 1.21$ & NS \\
\hline Digestibility of NDF & $71.60 \pm .60$ & $72.70 \pm .51$ & $71.40 \pm .76$ & $71.90 \pm .58$ & NS \\
\hline
\end{tabular}

Significant level= NS: Non Significant $=\mathrm{P}>0.05$; SE: Standard error; $\mathrm{T}_{0}=$ without calcium salt of fatty acid; $\mathrm{T}_{1=} 2.5 \%$ soybean oil based calcium salt of fatty acid; $\mathrm{T}_{2}=2.5 \%$ mustard oil based calcium salt of fatty acid; $\mathrm{T}_{3}=2.5 \%$ palm oil based calcium salt of fatty acid

Table 2. Effect of different types of calcium salt of fatty acid on milk yield and composition of different treatment group of Pabna lactating cows

\begin{tabular}{l|c|c|c|c|c}
\hline \multirow{2}{*}{ Parameter } & \multicolumn{3}{|c|}{ Mean \pm SE of different treatment group } & \multirow{2}{*}{$\begin{array}{c}\text { Level of } \\
\text { significance }\end{array}$} \\
\cline { 2 - 5 } & $\mathrm{T}_{0}$ & $\mathrm{~T}_{1}$ & $\mathrm{~T}_{2}$ & $\mathrm{~T}_{3}$ & \\
\hline \multicolumn{1}{c}{ Initial milk yield } & $2.86 \pm .21$ & $2.9 \pm .22$ & $2.84 \pm .48$ & $2.94 \pm .29$ & $\mathrm{NS}$ \\
$\quad$ Final milk yield & $2.44^{\mathrm{b}} \pm .15$ & $3.53^{\mathrm{a}} \pm .13$ & $3.33^{\mathrm{a}} \pm .21$ & $2.24^{\mathrm{b}} \pm .28$ & $* * *$ \\
Fat $\left(\mathrm{g} \mathrm{kg}^{-1}\right)$ & $4.01 \pm .21$ & $3.35 \pm .19$ & $3.55 \pm .19$ & $3.73 \pm .26$ & $\mathrm{NS}$ \\
Protein $\left(\mathrm{g} \mathrm{kg}^{-1}\right)$ & $3.65 \pm .02$ & $3.61 \pm .05$ & $3.70 \pm .05$ & $3.71 \pm .04$ & $\mathrm{NS}$ \\
Lactose $\left(\mathrm{g} \mathrm{kg}^{-1}\right)$ & $4.95 \pm .30$ & $5.21 \pm .07$ & $5.33 \pm .07$ & $5.34 \pm .06$ & $\mathrm{NS}$ \\
Solids not fat $\left(\mathrm{g} \mathrm{kg}^{-1}\right)$ & $9.67 \pm .06$ & $9.60 \pm .14$ & $9.83 \pm .13$ & $9.84 \pm .11$ & $\mathrm{NS}$ \\
Estimated mineral $\left(\mathrm{g} \mathrm{kg}^{-1}\right)$ & $0.65 \pm .02$ & $0.62 \pm .06$ & $0.67 \pm .02$ & $0.72 \pm .03$ & $\mathrm{NS}$ \\
\hline
\end{tabular}

Significant level $=($ Non Significant $=\mathrm{P}>0.05 ; * * *=\mathrm{P}<0.001$, highly significant $),{ }^{\text {abcd }}$ values with different 
superscripts in the same row differ significantly; SE: Standard error, $\mathrm{T}_{0}=$ without calcium salt of fatty acid; $\mathrm{T}_{1=} 2.5 \%$ soybean oil based calcium salt of fatty acid; $\mathrm{T}_{2}=2.5 \%$ mustard oil based calcium salt of fatty acid; $\mathrm{T}_{3}=2.5 \%$ palm oil based calcium salt of fatty acid

Table 3. Effect of different types of calcium salt of fatty acid on live weight changes of different treatment groups of Pabna lactating cow

\begin{tabular}{l|ccccc|c}
\hline \multirow{2}{*}{ Parameter } & \multicolumn{4}{c|}{ Mean $( \pm \mathrm{SE})$ of different treatment group } & \multirow{2}{*}{$\begin{array}{c}\text { Level of } \\
\text { significance }\end{array}$} \\
\cline { 2 - 5 } & $\mathrm{T}_{0}$ & $\mathrm{~T}_{1}$ & $\mathrm{~T}_{2}$ & $\mathrm{~T}_{3}$ & \\
\hline Initial Live weight $(\mathrm{kg})$ & $258.2 \pm 9.26$ & $265 \pm 13$ & $224 \pm 19.21$ & $253.2 \pm 13.09$ & $\mathrm{NS}$ \\
Final live weight $(\mathrm{kg})$ & $279.2 \pm 3.48$ & $285 \pm 7.73$ & $244.2 \pm 17.16$ & $269.8 \pm 10.01$ & $\mathrm{NS}$ \\
Live weight gain $(\mathrm{kg})$ & $21 \pm 10.47$ & $20 \pm 8.05$ & $20.2 \pm 5.77$ & $16.6 \pm 5.90$ & $\mathrm{NS}$ \\
$\begin{array}{l}\text { Daily live weight gain } \\
\left(\mathrm{kg} \mathrm{d}^{-1}\right)\end{array}$ & $0.70 \pm 0.34$ & $0.66 \pm 0.26$ & $0.67 \pm 0.19$ & $0.55 \pm 0.19$ & $\mathrm{NS}$ \\
\hline
\end{tabular}

Significant level $=$ NS: Non Significant $=\mathrm{P}>0.05$; $\mathrm{SE}$ : Standard error, $\mathrm{T}_{0}=$ without calcium salt of fatty acid; $\mathrm{T}_{1}=2.5 \%$ soybean oil based calcium salt of fatty acid; $\mathrm{T}_{2}=2.5 \%$ mustard oil based calcium salt of fatty acid; $\mathrm{T}_{3}=2.5 \%$ palm oil based calcium salt of fatty acid

\section{DISCUSSION}

The intake of total DM was higher in $\mathrm{T}_{2}$ group ( $2.5 \%$ calcium salt of fatty acid) may be due to efficient microbial growth which may not the exact cause. Wanapat and Khampa (2006) described that, the combined use of feeding with roughage and concentrate after $4 \mathrm{~h}$ with MSPF could improve rumen $\mathrm{P}^{\mathrm{H}}$, microbial protein synthesis but reduced protozoal population in dairy steers. Hristov et al. (2004) viewed long chain unsaturated fatty acid $\left(\mathrm{C}_{18: 3}, \mathrm{C}_{18: 2}, \mathrm{C}_{18: 1}\right)$ decreased protozoal numbers. But discrete or overall performances of roughage and concentrate did not differ significantly which was resembles to the findings of Klusmeyer et al., 1991. Feeding vegetable oils rich in linoleic acid (Go mez-Corte et al., 2008) also respond similarly was found. In case of apparent digestibility, Naik et al. (2009) evaluated that, there had no effect on apparent digestibility of DM and organic matter (OM) when calcium salts of long chain fatty acids (Ca-LCFA) as a rumen inert fat (PF) was used as adult buffalo feed. CP digestibility was not significantly differed among treatments as like as the findings of Voigt et al. (2006), in where carbohydrates and crude protein did not differ significantly. And, Schauff and Clark (1989) suggest that Ca salts of fatty acids were inert in the rumen and did not greatly alter fermentation in the rumen, apparent total tract digestibility of DM, organic matter, ADF, NDF, and CP. Significant improvement of milk yield was observed among treatments through incorporation of different types of $\mathrm{Ca}$ salts of fatty acid at $2.5 \%$ level in the concentrate mixture in this experiment. In the study of Sajith et al. (2008) got improved quality milk production without affecting the digestibility of nutrients through incorporation of polyunsaturated calcium salts of fatty acids at a $4 \%$ level in the concentrate mixture. By using calcium salts of fatty acids Rabiee et al. (2012) and Fahey et al. (2002) also obtained the similar result. There was no significant $(\mathrm{p}>0.05)$ 
difference for the parameters of milk protein, lactose, total minerals and SNF. Similar result was also reported by Perfield et al. (2002) except milk fat who conducted an experiment by feeding rumen protected CLA to pregnant cows.

\section{CONCLUSION}

Based on the above finding it may be concluded that, calcium salt of fatty acid formulated from soybean oil or mustard oil could be used for enhancing better quality milk yield and it may recognized as an effective technique.

\section{REFERENCES}

AOAC. (2005). Official Methods of Analysis, Centennial Edition. Association of Official Analytical Chemist, Washington DC.

Chalupa, W., Vecchiarelli, B., Elser, A.E., Kronfeld, D.S., Sklan, D., and Palmquist, D.L. (1986). Rumen fermentation in vitro as influenced by long chain fatty acids. Journal of Dairy Science, 69(5), 1293-1301.

Chalupa, W., Rickbaugh, B., Kronfeld, D.S. and Sklan, D. (1984). Rumen fermentation in vitro as influenced by long chain fatty acids. Journal of Dairy Science, 67, 1439-1450.

Chouinard, P.Y., Girard., and Brisson, G.J. (1988). Fatty acid profile and physical properties of milk fat from cows fed calcium salt of fatty acids with varying unsaturation. Journal of Dairy Science, 81, 471-481.

Fahey, J., Mee, J.F., Murphy, J.J., and O'Callaghan, D.(2002). Effects of calcium salts of fatty acids and calcium salt of methionine hydroxy analogue on plasma prostaglandin $\mathrm{F}_{2}$ alpha metabolite and milk fatty acid profiles in late lactation Holstein-Friesian cows. National Center for Biotechnology Information, U.S. National Library of Medicine. Theriogenology, 58(8), 1471-1482.

Go Mez-Corte, P., Frutos, S.P., Mantecon, A.R., Juarez, M., De la Fuente, M.A., and Hervast, G. (2008). Milk production, conjugated linoleic acids content, and in vitro ruminal fermentation in response to high levels of soybean oil in dairy cattle diet. Journal of Dairy Science, 91, 1560-1569.

Goering, H.K., and Van., Soest, P.J.(1970). Forage Fiber Analysis (Apparatus, Reagents, Procedures and Some Application). Agricultural Handbook No. 379, Agricultural Research Service, U.S. Department of Agriculture.

Grummer, R.R. (1988). Influence of prilled fat and calcium salt of palm oil acids on ruminal fermentation and nutrient digestibility. Journal of Dairy Science, 71, 117-123.

Harfoot, C.G. (1981). Lipid metabolism in the rumen. In: Lipid metabolism in ruminants animals. Edn. Pergamon Press, Oxford, UK.

Hristov, A.N., Ivan, M., and McAllister, T.A. (2004). In Vitro effects of individual fatty acids on protozoal numbers and on fermentation products in ruminal fluid from cattle fed a high- concentrate, barley-based diet. Journal of Animal Science, 82, 2693-2704.

Jenkins, T.C., and Palmquist, D.L. (1984). Effect of fatty acids or calcium soaps on rumen and total nutrient digestibility of dairy cows. Journal of Dairy Science, 67(5), 978-986. 
Kellogg, D.W., Pennington, Johnson, J.A., and Panivivat, Z.B. (2001). Survey of management practices used for the highest producing DHI herds in the United States. Journal of Dairy Science, 84, 120-127.

Klusmeyer, T.H., Lynch, G.L., Clark, J.H., and Nelson, D.R. (1991). Effects of calcium salts of fatty acids and protein source on ruminal fermentation and nutrient flow to duodenum of cows. Journal of Dairy Science, 74, 2206-2219.

Moallem, U., Folman, Y., and Sklan, D. (2000). Effects of somatotropin and dietary calcium soaps of fatty acids in early lactation on milk production, dry matter intake, and energy balance of high-yielding dairy cows. Journal of Dairy Science, 83, 2085-2094.

Naik, P.K., Saijpaul, S., and Rani, N. (2009). Effects of ruminally protected fat on in vitro fermentation and apparent nutrient digestibility in buffaloes. Journal of Animal Feed Science Technology, 153, 68-76.

Palmquist, D.L., and Jenkins, T.C. (1980). Fat in lactation rations: review. Journal of Dairy Science, 63(1), 1-14.

Palmquist, D.L., and Jenkins, T.C. (1982). Effects of added fat and calcium on in vitro formation of insoluble fatty acids soap and cell wall digestibility. Journal of Animal Science, 66, 957-970.

Perfield, I.J.W., Bernal-santos, G., Overton, T.R., and Bauman, D.E.(2002). Effects of dietary supplementation of rumen-protected conjugated linoleic acid in dairy cows during established lactation. Journal of Dairy Science, 85, 1609-1617.

Precht, D., Voigt, J., Hagemeister, H., and Kanitz, W. (2001). The influence of dietary rumen protected linoleic acid on milk fat composition, spreadability of butter and energy balance in dairy cows. European Journal of Lipid Science and Technology, 103, 783792.

Rabiee, A.R., Breinhild, K., Scott, W., Golder, H.M., Block, E., and Lean, I.J.( 2012). Effect of fat additions to diets of dairy cattle on milk production and components: a metaanalysis and meta-regression. Journal of Dairy Science, 95(6), 3225-3247.

Sajith, P., Anil, K., and Tiwari, D.P. (2008). Effect of Feeding Calcium Salts of Palm Oil Fatty Acids on Performance of Lactating Crossbred Cows. Asian-Australasian Journal of Animal Science, 21(3), 376-385.

Schauff, D.J., and Clark, J.H. (1989). Effects of prilled fatty acids and calcium salts of fatty acids on rumen fermentation, nutrient digestibilities, milk production, and milk composition. Journal of Dairy Science, 72(4), 917-927.

Staples, C.R., Burke, J.M., and Thatcher, W.W. (1998). Influence of supplemental fats on reproductive tissues and performance of lactating cows. Journal of Dairy Science, 81, 856-871

Sumida, C.R., Graber., and Nunez, E.(1993). Role of fatty acids in signal transduction: modulators and messengers. Prostaglandins Leukot Essent Fatty Acids, 48, 117-122.

Thatcher, W.W., Bilby, T., Staples, C.R., MacLaren, L., and Santos, J. (2004). Effects of polyunsaturated fatty acids on reproductive processes in dairy cattle. In Proc. Southwest Nutrition \& Management Conference, Bioproducts, Inc. Pre-Conference Symposium. Phoenix, AZ, February 26, 2004. 
Voigt, J., Kanitz, K., Precht, W., Becker, D., Schneider, F., Spitschak, F., Schonhusen, M., Junghans, U., Aschenbach, P., and Gdbel, J.R. (2005). Verwertung von glucose and langkettigenfetts duren durch die laktierende milch kuhbeifutter ungeinerfettan gereichertendidt. In: Deutsch. Tierdrztl. Wochenschr. 112, S423-425.

Voigt, J., Kuhla, S., Gaafar, K., Demo, M., and Hagemeister, H. (2006). Digestibility of rumen protected fat in cattle. Slovak Journal of Animal Science, 39(1-2), 16-19.

Wu, Z., Ohajuruka, O.A., and Palmquist, D.L. (1991). Ruminal synthesis, biohydrogenation, and digestibility of fatty acids by dairy cows. Journal of Dairy Science, 74, 3025-3034.

Steel, R.G.R., and Torrie, J.H. (1980). Principles and Procedures of Statistics: A Biometrical Approach. $2^{\text {nd }}$ Ed. McGraw-Hill Book Company, New York. 